\title{
特発性正常圧水頭症における脳循環障害と症状との関連
}

\author{
竹 内 東太郎 渡 邊一 夫* 清 水 庸 夫
}

\section{Relevances between Cerebral Circulatory Disorder and Symptom in Idiopathic Normal Pressure Hydrocephalus}

by

Totaro Takeuchi, M.D., Kazuo Watanabe, M.D., and Tsuneo Shimizu, M.D.

from

Department of Neurosurgery, KANTOH Neurosurgical Hospital, KANTOH Neurosurgical Institute

* Department of Neurosurgery, Southern TOHOKU Gerenal Hospital, Southern TOHOKU Research Institute for Neuroscience

The subjects were shunt-effective iNPH 40 patients. Before and one year after surgery, measurements of the cerebral circulatory dynamics (the cerebral blood flow pattern by ROI setting using ${ }^{123}$ I-IMP SPECT), and an evaluation of symptoms (gait disturbance: G, dementia : D, urinary incontinence: U) by grading scale (JNPHGSR). (1) Preoperative cerebral circulation and symptoms: As for the each symptoms and blood flow patterns, the severities of $\mathrm{G}(\mathrm{p}=0.017)$ in whole cortex non-reduction group (thalamus-basal ganglia reduction group) and D $(p=0.021)$ in whole cortex reduction group were obviously high compared with other symptoms particularly. (2) Circulation and symptoms one year after surgery: As the circulatory dynamics at different improvement sites and each symptoms, it was obviously mild for $\mathrm{G}(\mathrm{p}=0.003)$ in the group with an increased only thalamus-basal ganglia blood flow and increased both whole cortex and thalamus-basal ganglia blood flow and tend to mild for D $(p=0.091)$ in the group with an increased only whole cortex blood flow and increased both whole cortex and thalamus-basal ganglia blood flow compared with other symptoms.

(Received October 13, 2009; accepted February 9, 2010)

Key words : normal pressure hydrocephalus, idiopathic, cerebral blood flow, ${ }^{123}$ I-IMP SPECT, symptom

Jpn J Neurosurg（Tokyo）19:478-483, 2010

\section{はじめに}

特発性正常圧水頭症 (idiopathic normal pressure hydrocephalus：iNPH）における術前の低灌流部位や術後の灌 流改善部位に関して，従来よりさまざまな報告があ る5)899)12) 13)19)20)22)23). 以前われわれは, iNPH シャント有 效例で $\mathrm{N}$-isopropyl- ${ }^{123} \mathrm{I}-\mathrm{P}$-iodoamphetamine-single photon emission computed tomography ( ${ }^{123}$ I-IMP SPECT) を用 いた脳循環動態の検討を行い, iNPH における脳循環障
害では主に「脳皮質部」と「視床・基底核部 (脳室周辺)」 の灌流障害が惹起されることを提唱した22)。今回われわ れは，iNPH シャント有効例での灌流障害部位と症状と の関連性について検討したので報告する.

\section{対象および方法}

診断には iNPH 診療ガイドライン診断基準)を用い た. possible iNPH の診断は, (1)60 歳以上での発症, (2)

（医）啓清会関東脳神経外科病院脳神経外科 $/$ 干 360-0804 熊谷市代 1120 〔連絡先：竹内東太郎〕

Address reprint requests to: Totaro Takeuchi, M.D., Department of Neurosurgery, KANTOH Neurosurgical Hospital, KANTOH Neurosurgical Institute, 1120 Dai, Kumagaya-shi, Saitama 360-0804, Japan

* (財) 脳神経疾患研究所附属総合南東北病院脳神経外科 


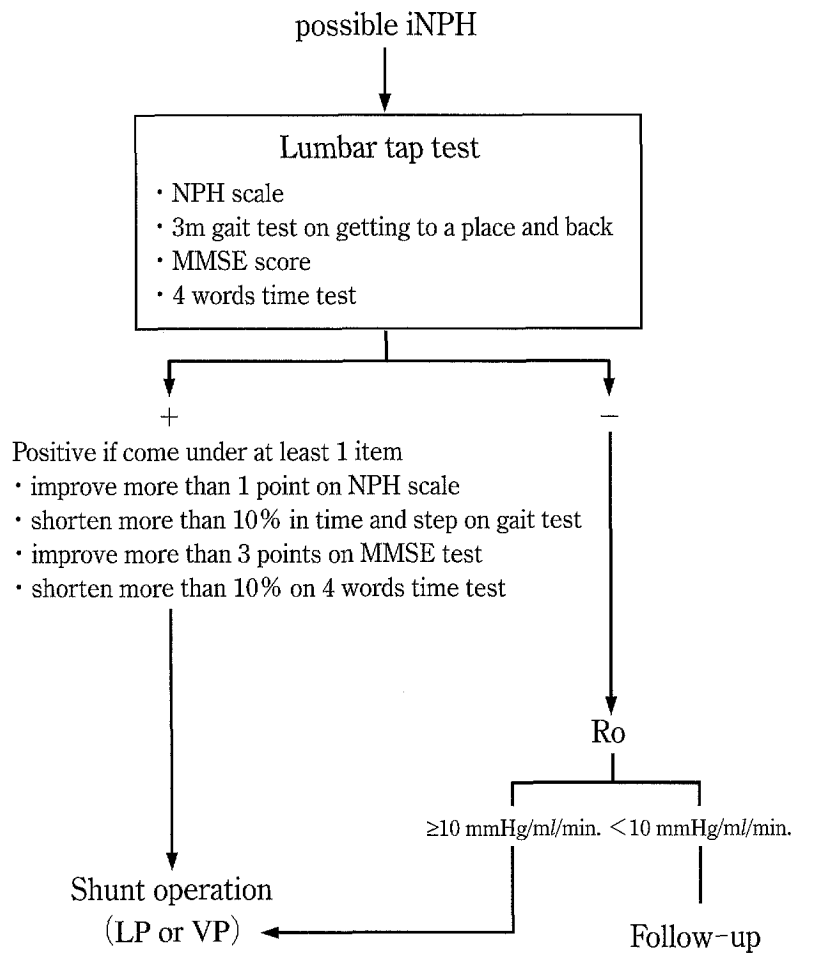

Fig. 1 Flowchart indication for shunting in patients with idiopathic normal pressure hydrocephalus ${ }^{22)}$

LP: lumboperitoneal shunting, $\mathrm{mCBF}$ : mean cerebral blood flow, MMSE: Minimental State Examination, NPH scale: Japanese normal pressure hydrocephalus grading scale-reviced ${ }^{4)}, \mathrm{V}-\mathrm{P}$ : ventriculo-peritoneal shunting

歩行障害・認知障害・尿失禁のうち 1 つ以上の症状を 有する，(3)Evans Index 0.3 以上の脳室拡大，(4)髄液圧が $200 \mathrm{mmH}_{2} \mathrm{O}$ 以下で能液成分が正常，(5)他疾患で症状の説 明不能, (6)既往疾患で脳窒拡大の説明不能の 6 項目を必 須項目とした。シャント手術適応は，iNPH 診療ガイド ライン診断基準4に準じて実施した。すなわち possible iNPH 症例に䯣液排除試験 (lumbar tap test：LTT) を施行 し, LTTにて症状改善か認められない例は龍迹液流出抵抗 值 (cerebrospinal fluid outflow resistance value: Ro) が 10 $\mathrm{mmHg} / \mathrm{ml} / \mathrm{min}$. 以上 ${ }^{20) 21)}$ をシャント適応とする，われわ れのシャント効果判定フローチャート ${ }^{22\rangle}$ (Fig. 1) に基づ き判定した。 シャント效果判定は, Japanese normal pressure hydrocephalus grading scale-reviced ${ }^{4)}$ (JNPHGS-R) を用い（Table 1)，歩行障害 $(G)$ ，認知障害 (D)，尿失 禁（U）の総計が 1 ポイント以上改善した例を有効とし た.

以上の条件でシャント手術が施行された 44 例のう ち, 術後 1 年後にシャント有効と判定された definite iNPH 40 例を対象とした。年齢は $61 〜 85$ 歳（平均年齢
Table 1 Japanese normal pressure hydrocephalus grading scale-reviced ${ }^{4)}$

\begin{tabular}{|c|c|}
\hline \multicolumn{2}{|c|}{ Gait disturbance $(\mathrm{G})$ : } \\
\hline 0 & normal \\
\hline 1 & unstable, only subjective gait disturbance \\
\hline 2 & objective gait disturbance, but independent gait \\
\hline 3 & walking with canes or walker frame \\
\hline 4 & walking not possible, wheelchair-bound \\
\hline \multicolumn{2}{|c|}{ Dementia (D) : } \\
\hline 0 & within normal range \\
\hline 1 & only subjective attention, memory disturbance \\
\hline & $\begin{array}{l}\text { objective attention, memory disturbance, but } \\
\text { normal time, place orientation }\end{array}$ \\
\hline 3 & $\begin{array}{l}\text { objective attention, memory disturbance with } \\
\text { time, place disorientation }\end{array}$ \\
\hline 4 & total disorientation, conversation not possible \\
\hline \multicolumn{2}{|c|}{ Urinary incontinence $(\mathrm{U})$ : } \\
\hline 0 & absent \\
\hline 1 & absent but pollakiuria or urinary urgency \\
\hline 2 & sometimes, more than $1-3$ time a day \\
\hline 3 & frequent, more than 1 time a day \\
\hline 4 & uncontrollable urinary incontinence \\
\hline
\end{tabular}

73.2 歳), 男女比は $18: 22$ であった。

SPECT は, 対象全例の術前および術後 1 年に ${ }^{123} I-I M P$ (Perfusamine $^{\circledR}$, 日本メジフィジックス) $222 \mathrm{MBq}$ 静注 し，Toshiba E. CAM（東芝メディカルシステムズ）を用 いて撮影した。脳血流量パターンは autoradiography 法3) により算出した，関心領域（ROI）は第三脳室と側脳室 が描出される axial sliceを基準として, 全皮質部（whole cortex blood flow : cCBF) と視床・基底核部付近（thalamus-basal ganglia blood flow：tbCBF）を設定した（Fig. 2). iNPH での $\mathrm{cCBF}$ および tbCBF の術前評佃は，当院 で施行した正常成人 10 人 $(60 \sim 77$ 歳, 平均年齢 69.5 歳, 男女比 6：4）における ${ }^{123}$ I-IMP SPECT での各 ROI の正 常成人平均局所脳血流量 (全皮質部: $44.82 \pm 4.02 \mathrm{ml} / 100$ $\mathrm{g} / \mathrm{min}$., 視床・基底核部付近: $48.38 \pm 3.51 \mathrm{ml} / 100 \mathrm{~g} /$ min.) と比較して, 各 ROI の数值が $10 \%$ 以上減少してい る例を血流量減少と判定した。術後評価は，同一症例の 同一部位の術前脳血流量と比較して, 数值が $10 \%$ 以上増 加している例を血流量増加と判定した。対象の術前およ び術後 1 年での脳灌流障害と JNPHGS-R による症状の 変化と関連性について検討した，有意差判定は，危険率 $5 \%$ 以下における Fisher's exact test 検定の p 值判定に より分析した. 


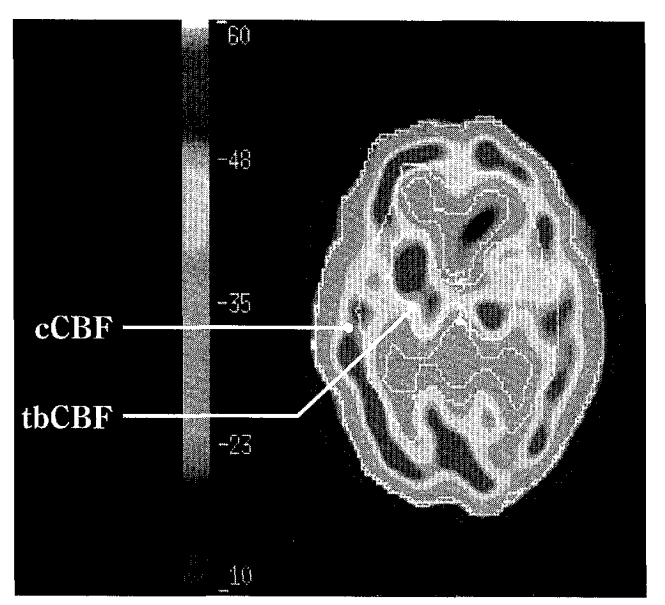

Fig. 2 Regions of interest on N-isopropyl- ${ }^{123} \mathrm{I}-\mathrm{P}-$ iodoamphetamine single photon emission computed tomography by autoradiography method $^{3)}$

cCBF : whole cortex blood flow, tbCGF : thalamusbasal ganglia blood flow

Table 3 Relationship between preoperative cerebral blood flow reduction patterns and symptoms by Japanese normal pressure hydrocephalus grading scale-reviced $^{4)}$

\begin{tabular}{|c|c|c|c|}
\hline & \multicolumn{2}{|c|}{ G } & \\
\hline & Grade $0 \sim 2$ & Grade $3 \sim 4$ & \\
\hline \multirow{4}{*}{$\begin{array}{l}\text { whole cortex } \\
\text { reduction }(-) \\
\text { whole cortex } \\
\text { reduction }(+)\end{array}$} & 0 & 9 & \multirow[b]{2}{*}{$\mathrm{p}=0.017$} \\
\hline & 13 & 18 & \\
\hline & \multicolumn{2}{|c|}{ D } & \\
\hline & Grade $0 \sim 2$ & Grade $3 \sim 4$ & \\
\hline \multirow{4}{*}{$\begin{array}{l}\text { whole cortex } \\
\text { reduction }(-) \\
\text { whole cortex } \\
\text { reduction }(+)\end{array}$} & \multirow[b]{2}{*}{7} & 3 & \multirow[b]{2}{*}{$\mathrm{p}=0.021$} \\
\hline & & 24 & \\
\hline & \multicolumn{2}{|c|}{$\mathrm{U}$} & \\
\hline & Grade $0 \sim 2$ & Grade $3 \sim 4$ & \\
\hline \multirow{2}{*}{$\begin{array}{l}\text { whole cortex } \\
\text { reduction }(-) \\
\text { whole cortex } \\
\text { reduction }(+)\end{array}$} & 9 & 0 & \multirow{2}{*}{$\mathrm{p}=0.074$} \\
\hline & 22 & 9 & \\
\hline
\end{tabular}

$\mathrm{D}$ : dementia, G: gait disturbance, $\mathrm{U}$ : urinary incontinence, whole cortex reduction $(-)=$ thalamusbasal ganglia reduction

The severities of $G(p=0.017)$ in whole cortex nonreduction group (thalamus-basal ganglia reduction group) and $\mathrm{D}(\mathrm{p}=0.021)$ in whole cortex reduction group were obviously high compared with other symptoms particularly.
Table 2 Preoperative cerebral blood flow reduction patterns on $\mathrm{N}$-isopropyl${ }^{123}$ I-P-iodoamphetamine single photon emission computed tomography by autoradiography method ${ }^{3)}$

\begin{tabular}{ccc}
\hline Type & $\begin{array}{c}\mathrm{cCBF} \\
(\mathrm{m} / / 100 \mathrm{~g} / \mathrm{min})\end{array}$ & $\begin{array}{c}\text { tbCBF } \\
(\mathrm{ml} / \mathbf{1 0 0} \mathrm{g} / \mathrm{min})\end{array}$ \\
\hline A $(\mathrm{n}=3)$ & $27.5 \pm 6.2$ & $45.1 \pm 7.9$ \\
B $(\mathrm{n}=9)$ & $47.7 \pm 2.8$ & $30.2 \pm 4.4$ \\
C $(\mathrm{n}=28)$ & $29.2 \pm 3.3$ & $31.0 \pm 5.3$ \\
\hline
\end{tabular}

cCBF : whole cortex blood flow, tbCBF : thalamusbasal ganglia blood flow, $\mathrm{A}$ : whole cortex reduction type, B : thalamus-basal ganglia reduction type, C: whole cortex \& thalamus-basal ganglia reduction type

\section{結 果}

\section{1 術前の脳循環動態と症状}

術前の autoradiography 法3)による脳血流量パターンを 正常成人平均局所脳血流量と比較して, $\mathrm{cCBF}$ 減少型 (A), tbCBF 減少型 (B), cCBF \& tbCBF 減少型 (C) の 3 型に分類した。各タイプの内訳は $\mathrm{cCBF}$ 減少型が 3 例, tbCBF 減少型が 9 例, $\mathrm{cCBF} \& \mathrm{tbCBF}$ 減少型が 28 例であり, cCBF \& tbCBF 減少型が全体の $70 \%$ と最も多 かった（Table 2)。統計処理のため，対象を $\mathrm{CCBF}$ 滅少 群（31 例）と cCBF 非減少群（=tbCBF 減少群：9例） に分け，JNPHGS-R での各症状の軽症（Grade 0〜2）と 重症（Grade 3〜4）の割合を検討した，Gでは $\mathrm{cCBF}$ 非 減少群 (=tbCBF 減少群) で有意に重症例が多かった $(\mathrm{p}=0.017)$. D では $\mathrm{cCBF}$ 隇少群で有意に重症例が多 かった $(\mathrm{p}=0.021)$ ，Uでは両群に有意差は認められな かった (Table 3).

\section{2 術後 1 年での脳循環動態の変化と症状}

術後 1 年での同一症例の術前同一部位との脳循環動 態の比較から, 循環動態改善部位の内訳は $\mathrm{cCBF}$ の夕増 加群が 6 例, tbCBF のみ増加群が 15 例, $\mathrm{cCBF}$ と tbCBF 堌加群が 19 例であった。 各群におけるJNPHGS-R での 各症状の軽症（Grade 0 2）と重症（Grade 3〜4）の割 合を検討した。 $\mathrm{G}$ では tbCBF 増加群および $\mathrm{cCBF} \&$ tbCBF 增加群で有意に軽症例が多かった $(\mathrm{p}=0.003) . \mathrm{D}$ では cCBF 増加群および cCBF \& tbCBF 増加群で軽症 例が多い傾向にあった $(\mathrm{p}=0.091)$ ，Uでは各群で有意差 は認められなかった（Table 4). 


\section{考 察}

iNPH における低灌流部位に関しては前頭葉灰白質が 主体であるとする報告が比較的多いが812213)，他に側頭 葉灰白質 ${ }^{12) 13)}$ ・頭頂葉灰白質9) ・ 視床や基底核部 5 ) ・ 傍脑 室分水嶺（watershed region）を含む脳室周囲白質23) ある いは脳全体に及ぶ灌流障害8)など，低灌流部位には実に さまざまな報告があるのが現状である.

術後の脳循環動態の変化では, 症状改善例でわれわれ を含め多くの諸氏が平均脳血流量や低灌流部位の有意な 改善を報告している ${ }^{5) 913320) 22223)}$. さらに術後における灌 流改善の程度は症状改善度と相関があり ${ }^{9) 23)}$, 歩行障害 と尿失禁は早期に, 認知障害は此較的遅く症状が改善す る傾向があるとされている6 ，以前われわれは ${ }^{123} I-I M P$ SPECT 用いて definite iNPH 40 例の検討を行い, iNPH では大別して「脳皮質部灌流障害」と「視床・基 底核部 (脳室周辺) 灌流障害」の 2 つの灌流障害が惹起 されること, iNPH の病期や進行度によって低灌流部位 がさまざまなパターンを呈し最終的には脳全体の灌流障

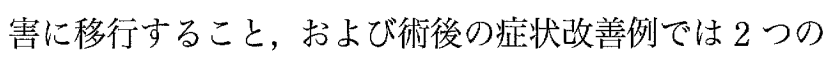
灌流障害部位のうち少なくとも 1 つの灌流障害が改善 することを報告した22).

今回われわれは，それらの低灌流部位と症状との関連 性について検討した。その結果, iNPH における低灌流 部位の主体が視床・基底核部（脳室周辺）では歩行障害 の重症例が他症状に比して有意に多く, 術後同部位の灌 流改善により歩行障害軽症例が有意に多いこと, 低灌流 部位の主体が脳皮質部では認知障害の重症例が他症状に 比して有意に多く, 術後同部位の灌流改善により認知障 害軽症例が多い傾向にあることがわかった。

iNPH で術前の低灌流部位と症状の局在との関連を検 討した報告の中で, 認知障害局在の主体が前頭葉, 特に 前頭前野に起因している可能性は以前から指摘されてい $3^{14) 17)}$. 今回の検討でも, 皮質部が認知障害に関与して いる可能性を示唆する結果であった。

歩行障害の局在に関して, Bugalho $ら^{2)}$ は前頭葉と基底 核部, Lee $ら^{10)}$, Mocco ら ${ }^{15)}$ は中脳, Ouchi $ら^{18)}$ は PET を用いた検討から dorsal putamen での postsynaptic $\mathrm{D}_{2}$ receptor の活動性低下が歩行障害の重症度を反映してい ると報告している。われわれは，(1)iNPH での歩行障害 がパーキンソン病の歩行障害と類似している点, (2) iNPH で歩行障害が最も高頻度で早期に発現し, 初発症 状が歩行障害である iNPH は術後の改善率が高い 点17)11)16)19), (3術後症状改善例で視床・基底核部（脳室 周辺）の灌流障害改善が最も多い点 ${ }^{22}$, それと今回の検
Table 4 Relationship between postoperative cerebral blood flow improvement and symptoms by Japanese normal pressure hydrocephalus grading scalereviced $^{4)}$

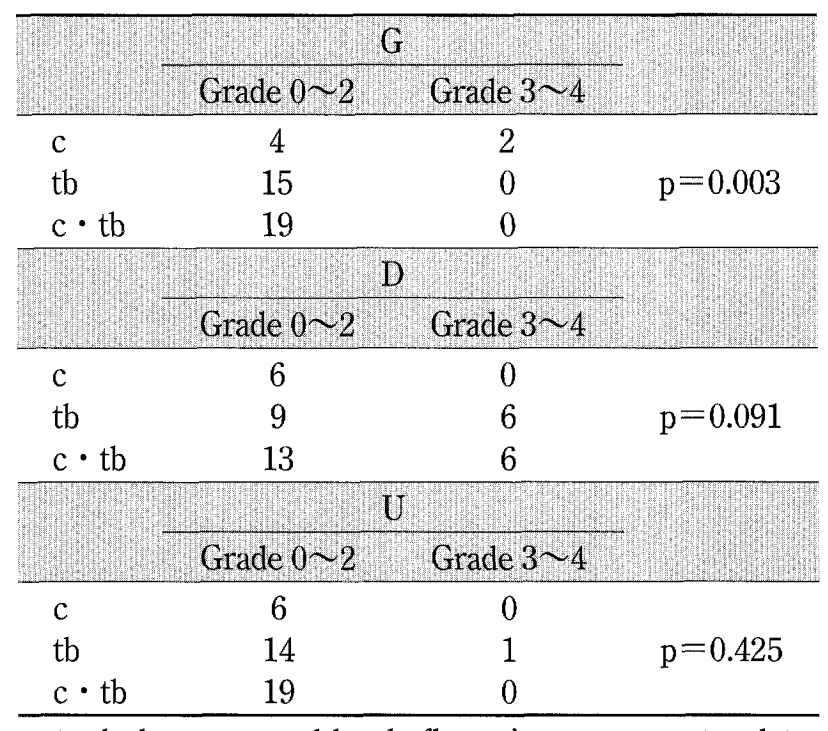

c: whole cortex blood flow improvement, tb: thalamus-basal ganglia blood flow improvement, $\mathrm{c} \cdot$ tb: whole cortex \& thalamus-basal ganglia blood flow improvement

It was obviously mild for $G(p=0.003)$ in the group with an increased only thalamus-basal ganglia blood flow and increased both whole cortex and thalamusbasal ganglia blood flow and tend to mild for $\mathrm{D}(\mathrm{p}=$ 0.091) in the group with an increased only whole cortex blood flow and increased both whole cortex and thalamus-basal ganglia blood flow compared with other symptoms.

討結果から(4)視床・基底核部（脳室周辺）が iNPH での 歩行障害局在の 1 つではないかと考えている，その場 合, 歩行障害の発現病態として, 脳室拡大による脳コン プライアンス低下に伴う周囲組織圧排, CSF lesser pathway, interstitial edema などにより脳室周辺の灌流障害が 惹起されて錐体外路系歩行障害が発現する可能性が推察 される. 歩行障害の特徴が「hypertonic, hypokinetic」で あることから，主に淡蒼球一中脳黒質に関与する錐体外 路線維を含む皮質春髄路の関与をわれわれは注目してい る.

\section{結 語}

${ }^{123} I$-IMP SPECTを用いて術後 1 年での definite iNPH 40 例について術前および術後 1 年の脳循環動態 と症状の変化を検討して, 以下の結論を得た。

1 ）術前低灌流部位の主体が視床・基底核部（脳室周 辺）の場合は，歩行障害の重症例が他症状に比して有意 
に多く, 術後同部位の灌流改善により歩行障害軽症例が 有意に多い.

2 ）術前低灌流部位の主体が脳皮質部の場合は認知障 害の重症例が他症状に比して有意に多く, 術後同部位の 灌流改善により認知障害軽症例が有意に多い傾向にあ る。

本論文の要旨は, 第 67 回日本脳神経外科学会学術総会 $(2008$ 年 10 月, 盛岡)にて発表した。

Acknowledgments: 本研究に抒ける症例の一部は, 日本正常圧水頭 症診療基準作成事業 (study of idiopathic normal pressure hydrocephalus on neurological improvement: SINPHONI）に提供した.

\section{文 献}

1) Bech-Azeddine R, Waldemar G, Knudsen GM, Høgh $P$, Bruhn P, Wildschiødtz G, Gjerris F, Paulson OB, Juhler $\mathrm{M}$ : Idiopathic normal-pressure hydrocphalus: Evaluation and findings in a multidisciplinary memory clinic. Eur $J$ Neurol 8: 601-611, 2001.

2) Bugalho P, Guimarães J: Gait disturbance in normal pressure hydrocephalus: A clinical study. Parkinsonism Ralet Disord 13: 434-437, 2007.

3) Hatazawa J, Iida $\mathrm{H}$, Shimosegawa E, Sato T, Murakami M, Miura Y : Regional cerebral blood flow measurement with iodine ${ }^{-123}$ IMP autoradiography : Normal values, reproducibility and sensitivity to hypoperfusion. J Nucl Med 38: 1102-1108, 1997.

4) Ishikawa M, Hashimoto M, Kuwana N, Mori E, Miyake H, Wachi A, Takeuchi T, Kazui H, Koyama H: Guidelines for management of idiopathic normal pressure hydrocephalus. Neurol Med Chir (Tokyo) 48 (Suppl): S1-S23, 2008.

5) Klinge P, Berding G, Brinker T, Weckesser E, Knapp WH, Samii M: Regional cerebral blood flow profiles of shuntresponder in idiopathic chronic hydrocephalus--A $155^{-0}-$ water PET-study. Acta Neurochir Suppl 81:47-49, 2002.

6) Klinge P, Rückert N, Schuhmann M, Berding G, Brinker T, Knapp WH, Samii M: Neuropsychological sequels to changes in global cerebral blood flow and cerebrovascular reserve capacity after shunt treatment in chronic hydrocephalus - A quantitative PET-study. Acta Neurochir Suppl 81: 55-57, 2002.

7) Krauss JK, Regel JP, Vach W, Borremans JJ, Mergner T: Vascular risk factors and arteriosclerotic disease in idiopathic normal-pressure hydrocephalus of the elderly. Stroke 27:24-29, 1996.

8) Kristensen B, Malm J, Fagerland M, Hietala SO, Johansson B, Ekstedt J, Karlsson T: Regional cerebral blood flow, white matter abnormalities, and cerebrospinal fluid hydrodynamics in patients with idiopathic adult hydrocephalus syndrome. J Neurol Neurosurg Psychiatry 60: 282-288, 1996.

9) Larsson A, Bergh AC, Bilting M, Arlig A, Jacobsson L, Stephensen H, Wikkelsö C: Regional cerebral blood flow in normal pressure hydrocephalus: Diagnostic and prognostic aspects. Eur J Nucl Med 21: 118-123, 1994.

10) Lee PH, Yong SW, Ahn YH, Huh $\mathrm{K}$ : Correlation of mid- brain diameter and gait disturbance in patients with idiopathic normal pressure hydrocephalus. J Neurol 252: 958-963, 2005.

11) McGirt MJ, Woodworth G, Coon AL, Thomas G, Williams MA, Rigamonti D: Diagnosis, treatment, and analysis of long-term outcome in idiopathic normal-pressure hydrocephalus. Neurosurgery $\quad \mathbf{5 7}: 699-705,2005$.

12) Meyer JS, Tachibana H, Hardenberg JP, Dowell RE Jr, Kitagawa $\mathrm{Y}$, Mortel $\mathrm{KF}$ : Normal pressure hydrocephalus: Influences on cerebral hemodynamic and cerebrospinal fluid pressure: Chemical autoregulation. Sur Neurol 21: 195-203, 1984.

13) Meyer JS, Kitagawa $Y$, Tanahashi N, Tachibana H, Kandula P, Ceck DA, Clifton GL, Rose JE : Evaluation of treatment of normal-pressure hydrocephalus. J Neurosurg 62: 513-521, 1985.

14) Miyoshi N, Kazui H, Ogino A, Ishikawa M, Miyake H, Tokunaga H, Ikejiri Y, Takeda M: Association between cognitive impairment and gait disturbance in patients with idiopathic normal pressure hydrocephalus. Dement Geriatr Cogn Disord 20:71-76, 2005.

15) Mocco J, Tomey MI, Komotar RJ, Mack WJ, Frucht SJ, Goodman RR, Mckhann GM 2nd: Ventriculoperitoneal shunting of idiopathic normal pressure hydrocephalus increases midbrain size: A potential mechanism for gait improvement. Neurosurgery 59:847-850, 2006.

16) Mori $\mathrm{K}$ : Management of idiopathic normal-pressure hydrocephalus: A multiinstitutional study conducted in Japan.J Neurosurg 95: 970-973, 2001.

17) Ogino A, Kazui H, Miyoshi N, Hashimoto M, Ohkawa S, Tokunaga $\mathrm{H}$, Ikejiri $\mathrm{Y}$, Takeda $\mathrm{M}$ : Cognitive imparement in patients with idiopathic normal pressure hydrocephalus. Dement Geriatr Cogn Disord 21 : 113- 119, 2006.

18) Ouchi Y, Nakayama T, Kanno T, Yoshikawa E, Shinke T, Torizuka T: In vivo presynaptic and postsynaptic striatal dopamine functions in idiopathic noromal pressure hydrocephalus. J Cereb Blood Flow Metab 27: 803-810, 2007.

19）竹内東太郎, 笠原英司, 岩崎光芳: 脳萎縮を伴う特発性 正常圧水頭症 (非定型特発性正常圧水頭症) : その臨床的 特徽とシャント手術適店. No Shinkei Geka 28：505$515,2000$.

20) Takeuchi T, Kasahara E, Iwasaki M, Mima T, Mori K : Indications for shunting in patients with idiopathic normal pressure hydrocephalus presenting with dementia and brain atrophy (atypical idiopathic normal pressure hydrocephalus). Neurol Med Chir (Tokyo) 40:38-47, 2000.

21）竹内東太郎, 後藤博美, 伊崎堅志, 国分康平, 小田正哉, 箅沼仁一, 前野和重, 菊地泰裕, 小泉仁一, 渡辺善一郎, 伊藤康信, 大原宏夫, 古和田正悦, 渡邊一夫: 特発性正 常圧水頭症に㧍ける䝵液流出抵抗值の再検討一硬膜外圧 測定と腰部くも膜下腔䯋液圧との比較一. No Shinkei Geka 33: 579-584, 2005.

22) Takeuchi T, Goto H, Izaki K, Tamura S, Tomii M Sasanuma J, Maeno K, Kikuchi Y, Koizumi J, Watanabe Z, Numazawa S, Itoh Y, Watanabe K, Kojima M, Mishima M, Onishi Y, Okada T, Arai T: Pathophysiology of cerebral circulatory disorders in idiopathic normal pressure hydrocephalus. Neurol Med Chir (Tokyo) 47:299-306, 2007.

23) Tanaka A, Kimura M, Nakayama Y, Yoshinaga S, Tomon- 
aga $\mathrm{M}$ : Cerebral blood flow and autoregulation in normal pressure hydrocephalus. Neurosurgery $40: 1161-1167$,
1997.

\section{要}

旨

\section{特発性正常圧水頭症における脳循環障害と症状との関連 \\ 竹内東太郎 渡邊 一夫 清水 庸夫}

術後 1 年でシャント有効と判定された特発性正常圧水頭症（iNPH） 40 例の術前・術後 1 年におけ る 状（歩行障害：G，認知障害：D，尿失禁：U）との関連性について検討した. (1)術前の脳循環動態と 症状：脳血流量減少パターンと JNPHGS-R での各症状の比較では，全皮質部非減少群（視床·基底 核部減少群) で $G(p=0.017)$, 全皮質部減少群で $D(p=0.021)$ の重症例が他症状に比して有意に 多かった. (2)術後 1 年での脳循環動態と症状：脳循環動態改善部位と JNPHGS-R での各症状との検 討では，視床・基底核部血流改善群および全皮質部\&視床・基底核部血流改善群では $G(p=0.003)$ の軽症例が有意に多く、全皮質部血流改善群および全皮質部\&視床 ・ 基底核部血流改善群では $D(p=$ 0.091）の軽症例が多い傾向にあった．iNPH での症状局在の一つとして，認知障害では脳皮質部，歩 行障害では視床・基底核部（脳室周辺）が推察された。

脳外誌 $19: 478-483,2010$

\section{Editorial Comment}

\section{iNPH に伴う歩行障害の責任痌巣について}

順天堂大学脳神経外科 宮嶋雅一

本論文は，iNPH 40 例を対象とした SPECT によ る定量的脳血流測定により，iNPH の歩行障害は大 脳皮質よりもむしろ大脳基底核に起因するとする新 たな知見が得られた論文である。症候学的には iNPH の歩行障害は, broad-based, short-step, magnetic gait with start hesitation, increased instability on turning などの特徵を有する失行性歩行で,その原因 は前頭葉と考えられている。さらにXe-CTや SPECT による脳血流測定の結果からも前頭葉の血 流の低下を指示する報告が多い。一方，著者らも考
察で引用されているPET を用いた最近の研究では, dorsal putamen の postsynaptic $\mathrm{D}_{2}$ receptor の活動性 低下が歩行障害に関連しているとの報告もある。ま た, iNPH はしばしば Parkinson 病などの神経変性疾 患と合併することもあり，そのような症例では歩行 障害の原因は大脳基底核にあると考えられる。この 諭文の結果に対しては，多くの神経内科医からの反 論があると予想されるが, 統計学的解析により有意 差が示された結果は公表されるべきであると思われ る。 